Vietnam Academy of Science and Technology
Vietnam Journal of Earth Sciences
http://www.vjs.ac.vn/index.php/jse

\title{
Human exposure to radon radiation geohazard in Rong Cave, Dong Van Karst Plateau Geopark, Vietnam
}

\author{
Nguyen Thi Anh Nguyet ${ }^{1}$, Nguyen Thuy Duong*1, Arndt Schimmelmann², Nguyen Van Huong ${ }^{1}$ \\ ${ }^{1}$ VNU University of Science, Vietnam National University, Hanoi, Vietnam \\ ${ }^{2}$ Indiana University, Department of Earth and Atmospheric Sciences, Bloomington, Indiana, USA
}

Received 5 October 2017; Received in revised form 28 December 2017; Accepted 13 March 2018

\begin{abstract}
Rong Cave is one of the more important caves in northern Vietnam's Dong Van Karst Plateau Geopark (part of the Global Geoparks Network), because its subterranean lake provides agricultural and domestic water for neighboring communities. Maintenance and utilization of Rong Cave's water reservoir, as well as touristic cave use, require frequent human access to Rong Cave. Depending on the availability of seasonal drip water and the water level of the lake, the abundant clay-rich sediment in the back portion of Rong Cave and possible seepage of gas from deeper strata along geologic faults provide seasonally elevated concentrations of radon in cave air. Based on repeated measurements over 10 months in 2015 and 2016 of the concentrations of radon isotopes $\left({ }^{222} \mathrm{Rn}\right.$ and ${ }^{220} \mathrm{Rn}$, also called thoron) with a portable SARAD ${ }^{\circledR}$ RTM 2200 instrument $\left(\right.$ SARAD $^{\circledR} \mathrm{GmbH}$, Germany), the human total annual inhalation dose was estimated according to the UNSCEAR (2000) algorithm. The result indicates that the radon-related radiation exposure is insignificant for short-term visitors but may reach $\sim 1.8 \mathrm{mSv} \mathrm{a}^{-1}$ for tour guides and $\sim 25 \mathrm{mSv} \mathrm{a}^{-1}$ for cave utility workers. The latter values exceed the IAEA-recommended safety threshold of $1 \mathrm{mSv} \mathrm{a}^{-1}$ (IAEA, 1996). We recommend radiation monitoring for cave utility workers and tour guides. Prolonged human presence in Rong Cave should be avoided during periods of seasonally elevated radon concentrations.
\end{abstract}

Keywords: annual radioactive dose rate; cave air; geohazard; radon; Rong Cave; thoron.

(C)2018 Vietnam Academy of Science and Technology

\section{Introduction}

Radon is a radioactive noble gas that occurs in trace amounts in the atmosphere and consists of radiogenic isotopes ${ }^{222} \mathrm{Rn},{ }^{220} \mathrm{Rn}$ and ${ }^{219} \mathrm{Rn}$ as intermediate nuclides from radioactive decay chains originating from longlived nuclides uranium-238 $\left.{ }^{238} \mathrm{U}\right)$, thorium $\left({ }^{232} \mathrm{Th}\right)$, and ${ }^{235} \mathrm{U}$, respectively (WHO, 2000). Radon's parental metallic nuclides in the

"Corresponding author, Email: duongnt_minerals@vnu.edu.vn earth's crust decay within minerals in soil, rock, building bricks or concrete to produce radon atoms that can be released from solid phases and enter pore spaces, from where radon can be exhaled into the atmosphere. The 3.96 seconds half- life of the relatively rare ${ }^{219} \mathrm{Rn}$ nuclide is too short to allow the exit from a solid phase and significant transfer into air where ${ }^{219} \mathrm{Rn}$ and its progeny can be inhaled by humans. In contrast, the longer-lived radon isotopes ${ }^{222} \mathrm{Rn}$ (half life 3.83 days, decay energy $5.59 \mathrm{MeV}$ ) and ${ }^{220} \mathrm{Rn}$ (also called thoron, 
Nguyen Thi Anh Nguyet, et al./Vietnam Journal of Earth Sciences 40 (2018)

half life 55.6 seconds, $6.29 \mathrm{MeV}$ ) can more efficiently enter the atmosphere where they and their metallic radioactive progeny can be inhaled (Meisenberg et al., 2017, and references therein). Both radon and metallic progeny are easily dissolved in lymph and blood in lungs or adsorbed to tissue. Radioactive decay results in $\alpha, \beta$, and $\gamma$-radiation, out of which $\alpha$ decay is most prominent along the decay chain of radon isotopes. Cumulative radiationinduced damage of tissue can result in carcinoma, most prominently lung cancer (WHO, 2000).

Inhalation of radon and its metallic radioactive daughter nuclides in air is responsible for about half of the annual average effective dose from natural sources of radiation received by humans (UNSCEAR, 2000). It appears that evolution has equipped humans with biochemical repair mechanisms to avoid negative health effects from low radon concentrations. However, high levels of radon are known to pose a radiation geohazard to human health, for example in poorly ventilated rooms and caves where radon and its metallic progeny can accumulate in stagnant air. Monoatomic radon readily diffuses through porous materials and can be exhaled from dry soil and limestone in karst environments (Gunn, 2003). Furthermore, radon can be transported along geologic fractures from deeper strata into caves and to earth's surface with the help of fast-moving water and carrier gases, such as carbon dioxide, $\mathrm{CO}_{2}$ (Etiope and Martinelli, 2002; Walia et al., 2010). Karst caves are frequently aligned with, or intersected by geologic faults that facilitate transport of fluids. The air in many caves is known to contain elevated radon concentrations that can be problematic for human health (ICRP, 2003; Cigna, 2005; Dumitru et al., 2015).

We explored radon concentrations in the air of several karst caves in the Dong Van Karst Plateau Geopark during "warm and wet", "cold and wet", and "cold and dry" weather conditions in 2015 and 2016 (Nguyen
Thuy Duong et al., 2016). Rong Cave's radon concentrations in cave air generally fluctuated widely in response to (i) cave air ventilation rates depending on the difference between cave and outside temperatures, and (ii) percolating and drip water saturating cave sediment and affecting radon exhalation and gas seepage through geologic faults. Rong Cave has been one of the first caves in the Dong Van Karst Plateau Geopark to be developed for tourism. In contrast to other surveyed caves, Rong Cave's intensity of direct $\alpha$-radiation from ${ }^{222} \mathrm{Rn}$ alone, and even more so the cumulative radiation from ${ }^{222} \mathrm{Rn},{ }^{220} \mathrm{Rn}$, and their progeny exceeded the recommended safety radiation threshold for human health. This raises concern especially for utility workers and tour guides, who spend considerably more time in Rong Cave than visiting tourists. Rong Cave showed the highest radon concentrations of all surveyed caves in the Dong Van Karst Plateau Geopark. While this result spells relief for better ventilated caves in the area, the example of Rong Cave comes as a warning for caves that have not yet been surveyed during different seasons.

This study focuses on estimating the human inhalation dose in the air of Rong Cave from radon isotopes ${ }^{222} \mathrm{Rn}$ and ${ }^{220} \mathrm{Rn}$ during either "warm and wet", "cold and wet", or "cold and dry" weather conditions outside of the cave. Specific safety recommendations are based on seasonally different radiation doses that expose utility workers, tour guides, and visitors to the health risks.

\section{Geological features and technical infra- structure of Rong Cave}

Rong Cave is situated close to the Sang Tung Commune in the Dong Van District on the Dong Van Karst Plateau within the first Global Geopark in Vietnam (GGN, 2010). Rong Cave stretches mainly in a Northwest Southeast direction (Nguyen Van Huong et al., 2016) within the Hong Ngai Formation 
( $\left.\mathrm{T}_{1} h n\right)$ (Tong-Dzuy Thanh and $\mathrm{Vu}$ Khuc, 2011) commonly consisting of dark to grey, thin to medium-bedded marl interbedded with black-grey argillaceous limestone. Argillaceous coaly limestone is exposed locally near Rong Cave's entrance and along some cave walls, with many features being similar to the lower section of the Hong Ngai Formation as described by Tong-Dzuy Thanh and $\mathrm{Vu}$ Khuc (2011).

Rong Cave has a single narrow entrance with a secured gate at an altitude of $1440 \mathrm{~m}$ above sea level (latitude $23^{\circ} 12^{\prime} 43.48^{\prime \prime} \mathrm{N}$, longitude $\left.105^{\circ} 14^{\prime} 11.75^{\prime \prime} \mathrm{E}\right)$. A relatively straight, $\sim 350 \mathrm{~m}$ long and up to $50 \mathrm{~m}$ tall passage with a concrete-paved path and short bridges connects to a voluminous terminal chamber extending over $\sim 3500 \mathrm{~m}^{2}$ before abruptly sinking to a depression holding $\mathrm{a} \sim 1500 \mathrm{~m}^{2}$ large subterranean lake (Figure $1 \mathrm{~A}$ and $1 \mathrm{~B}$ ). The cave features stalagmites and 'hanging slime threads' of unknown biological origin (Nguyen-Thuy et al., 2017) in parts of the long passage towards the voluminous terminal room (Figure 1B1 and 1B2).

At a distance of $\sim 150 \mathrm{~m}$ from the entrance, slickensides indicate a geologic fault intersecting the passage (Figure 1B4). The floor of some sections of the passage and most of the terminal chamber is covered with red clayrich sediment (Figure 1B5). The central section of the large chamber features an extended elevated clay plateau a few meters above the lake level. A laminated sequence of clay deposition is visible at an erosional cut along the plateau, which indicates that the water level had occasionally been much higher in the past and even flooded the plateau. The modern lake level fluctuates in response to monsoonal lake recharge and seasonal water withdrawal. A pumping station with a floating water intake near the center of the lake connects to a steel pipeline that continues through the cave's passage to the Sang Tung Commune (Figure 1B6). Electric cables run parallel to steel pipes to supply electricity for pumps and lighting along the cave's path. The commune employs four utility workers who daily access the cave for operation and maintenance of pumps and the water distribution system.

\section{Survey of radon concentrations in cave air}

Radon-222 and radon-220 concentrations were measured in various locations in Rong Cave on May $5^{\text {th }}$ and from December $2^{\text {nd }}$ to $3^{\text {rd }}$ in 2015, and on March $14^{\text {th }}$ in 2016. A portable SARAD ${ }^{\circledR}$ RTM 2200 instrument (SAR$\mathrm{AD}^{\circledR} \mathrm{GmbH}$, Germany) with an internal diaphragm pump generated an air flow of $1 \mathrm{~L}$ $\min ^{-1}$ into the measurement chamber for $\alpha$ spectroscopic quantification of ${ }^{222} \mathrm{Rn}$ and ${ }^{220} \mathrm{Rn}$ in cave air. ${ }^{222} \mathrm{Rn}$ and ${ }^{220} \mathrm{Rn}$ concentrations were calculated based on the signals from the sum of ${ }^{218} \mathrm{Po}$ and ${ }^{214} \mathrm{Po}$, and from ${ }^{216}$ Po, respectively. Air was sampled from $1 \mathrm{~m}$ above the ground for at least 3 measurement cycles of 10 minutes each.

Radon concentrations in the air of Rong Cave were measured during three campaigns in May 2015, December 2015, and March 2016 corresponding to either "warm and wet", "cold and wet", or "cold and dry" weather conditions outside of the cave (GSO, 2016). The respective average ${ }^{222} \mathrm{Rn}$ and ${ }^{220} \mathrm{Rn}$ concentrations were $5956 \mathrm{~Bq} \mathrm{~m}^{-3}$ and $492 \mathrm{~Bq} \mathrm{~m}^{-3}$ during "warm and wet" weather conditions, $873 \mathrm{~Bq} \mathrm{~m}^{-3}$ and $546 \mathrm{~Bq} \mathrm{~m}^{-3}$ during "cold and wet" conditions, and $206 \mathrm{~Bq} \mathrm{~m}^{-3}$ and $74 \mathrm{~Bq} \mathrm{~m}^{-}$ 3 during "cold and dry" conditions (Nguyễn Thuy Duong et al., 2016). Radon concentrations were also reported by Nguyen Anh et al., (2016) and are shown in Table 1. 
Vietnam Journal of Earth Sciences, 40(2), 117-126

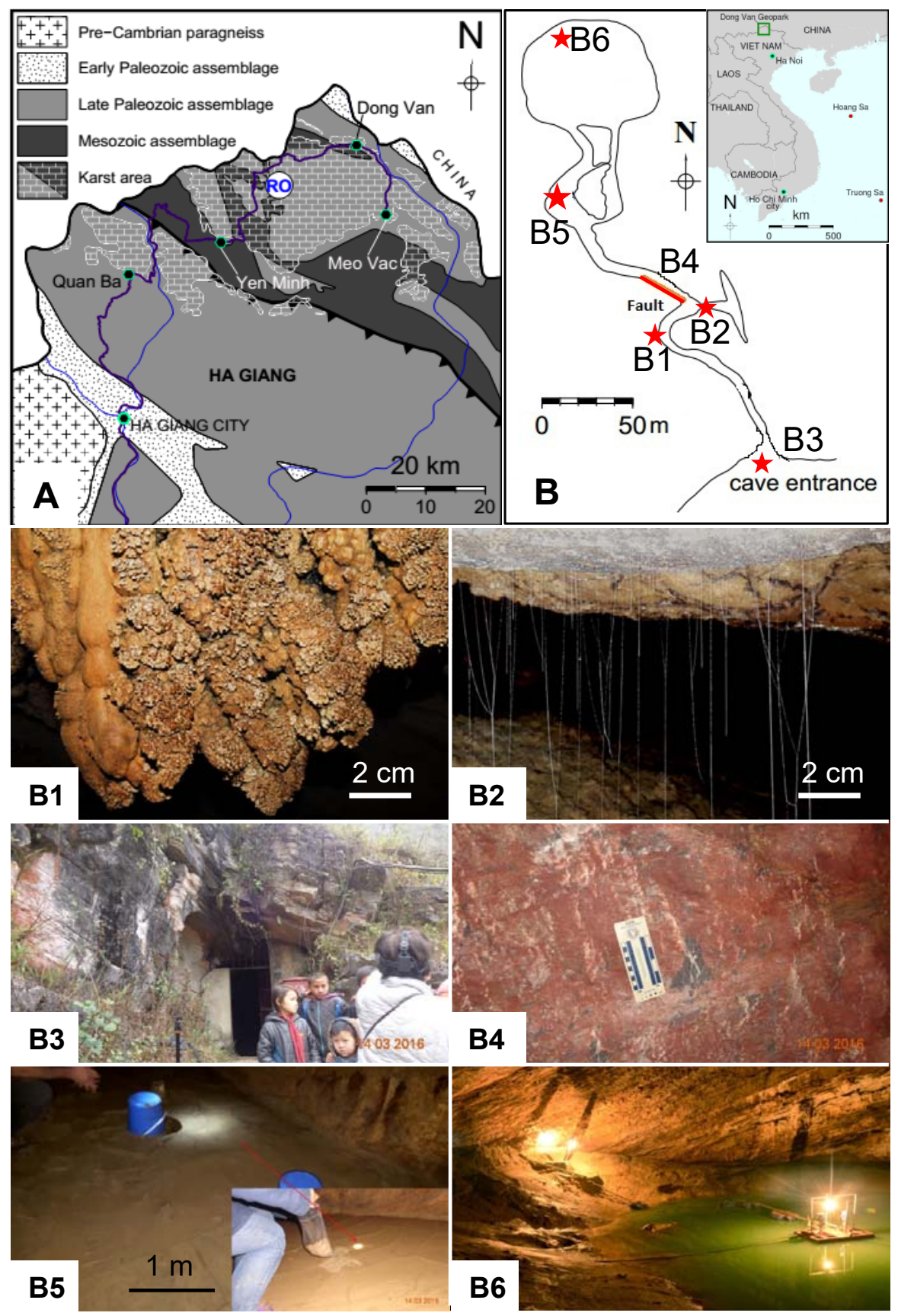

Figure 1. Location (A) and main features (B) of Rong Cave in Dong Van Karst Plateau Geopark. (B1) Stalactites and (B2) 'slime/silk threads' of unknown biological origin; (B3) Single narrow entrance with a secured gate; (B4) slickenside indicating a geologic fault intersecting the passage; the scale is $10 \mathrm{~cm}$ long; (B5) the floor of some lower cave sections is covered with red clay-rich sediment; (B6) a depression near the end of Rong Cave with a diameter of $\sim 50$ $\mathrm{m}$ is used as a water reservoir with a central floating water intake 
Vietnam Journal of Earth Sciences, 40(2), 117-125

Table 1. Minimum, maximum, and mean radon concentrations in the air of Rong Cave from different measurement campaigns (including air at the cave entrance, but excluding air in small local depressions and along faults in the cave). The descriptions 'in' and 'out' refer to air within the cave and external air outside of the cave's entrance

\begin{tabular}{|c|c|c|c|c|c|}
\hline $\begin{array}{l}\text { Weather condi- } \\
\text { tions outside } \\
\text { of the cave }\end{array}$ & $\begin{array}{c}\text { Dates of field } \\
\text { work }\end{array}$ & $\begin{array}{l}\text { Temperature } \\
\text { (in; out) }\left({ }^{\circ} \mathrm{C}\right)\end{array}$ & $\begin{array}{l}\text { Relative humidi- } \\
\text { ty (in, out) } \\
(\% \mathrm{H})\end{array}$ & $\begin{array}{l}{ }^{222} \mathrm{Rn}(\min -\max ) \\
\text { mean }\left(\mathrm{Bq} \mathrm{m}^{-3}\right)\end{array}$ & $\begin{array}{l}{ }^{220} \mathrm{Rn}(\min -\max ) \\
\left.\text { mean }(\mathrm{Bq} \mathrm{m})^{-3}\right)\end{array}$ \\
\hline Warm and wet & May $5^{\text {th }}, 2015$ & $21 ; 30$ & $65 ; 59$ & $(2870-8006) ; 5956$ & $(388-1163) ; 492$ \\
\hline Cold and wet & $\begin{array}{l}\text { December } 2^{\text {nd }}- \\
3^{\text {rd }}, 2015\end{array}$ & $18 ; 24$ & $69 ; 62$ & $(178-5527) ; 873$ & $(455-910) ; 546$ \\
\hline Cold and dry & March $14^{\text {th }}, 2016$ & $17 ; 23$ & $65 ; 40$ & $(144-288) ; 206$ & $(37-111) ; 74$ \\
\hline
\end{tabular}

\section{Procedure for assessment of annual radiation dose}

$\alpha$-Decay of radon in air generates radioactive metal ions that tend to become adsorbed to aerosol and dust particles in the air. Inhalation of radon and its radiogenic metallic daughter nuclides causes solution into body fluid and adsorption to lung tissue. Radionuclides can also enter the human body via eating and drinking, although these pathways are deemed less important in cave environments. All types of radiation from radioactive decay processes can induce harmful random biochemical reactions, including damage to DNA (WHO, 2000). Cell damage from exposure to high radon concentrations is known to enhance the incidence of lung cancer. The World Health Organization recommended an

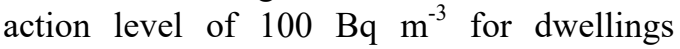
(WHO, 2000), which considers lower levels safe for human habitation (WHO, 2000). This level can be raised to no more than $300 \mathrm{~Bq} \mathrm{~m}^{3}$ if prevailing country-specific conditions apply (UNSCEAR, 2008). The International Atomic Energy Agency (IAEA, 1996) specified an annual dose limit of $1 \mathrm{mSv}^{-1}$ for human exposure. Doses from radon and radon progeny can also be calculated using various models. This study uses the following UNSCEAR (2000) algorithm:

$\mathrm{D}=\left[\left(\mathrm{k}_{\mathrm{Rn}}+\mathrm{n}_{\mathrm{Rn}} \times \mathrm{F}_{\mathrm{Rn}}\right) \times \mathrm{C}_{\mathrm{Rn}}+\left(\mathrm{k}_{\mathrm{Tn}}+\mathrm{n}_{\mathrm{Tn}} \times\right.\right.$ $\left.\left.\mathrm{F}_{\mathrm{Tn}}\right) \times \mathrm{C}_{\mathrm{Tn}}\right] \times \mathrm{H}$

where $\mathrm{Rn}={ }^{222} \mathrm{Rn}$; $\mathrm{Tn}={ }^{220} \mathrm{Rn}$

- $\mathrm{k}$ : solubility coefficient blood $\left(k_{R n}=\right.$ $0.17 ; k_{T n}=0.11$ )
- $\mathrm{n}$ : inhalation dose conversion factor $\left.\left(\mathrm{nSv} /(\mathrm{Bq} \mathrm{h} \mathrm{m})^{-3}\right)\right)\left(n_{R n}=9 ; n_{T n}=40\right)$

- F: equilibrium factor

indoor $\left(F_{R n}=0.4 ; F_{T n}=0.3\right)$; outdoor $\left(F_{R n}\right.$ $\left.=0.6 ; F_{T n}=0.1\right)$

- $\mathrm{H}$ : average time exposure in year $(\mathrm{h})$

- C: concentration $\left(\mathrm{Bq} \mathrm{m}^{-3}\right)$

- D: inhalation dose $\left(\mathrm{mSv}^{-1}\right)$

The equilibrium factor is the ratio of potential $\alpha$ energy concentration (PAEC) of the actual mixture of radon decay products to that which would apply at dynamic equilibrium concentrations of radionuclides (ICRP, 2010).

\section{Estimates of human inhalation dose in Rong Cave}

Rong Cave is routinely visited by utility workers, tour guides, and tourists. A typical touristic cave visit lasts on average 2 hours and is not repeated in the same year. In contrast, tour guides accompany tourists on multiple occasions per year, which is most frequent during the "cold" season and least frequent in the touristically unfavorable 'warm and wet' monsoon season. Our estimates of inhalation dose in Rong Cave assume (i) a daily average 4-hour presence in the cave by utility workers regardless of season and outside weather, (ii) occasional 2-hour walks through Rong Cave offered by tour guides primarily during the tourist season from mid-October to March (i.e., 2 weeks in "warm and wet" weather, 3 months in "cold and wet" weather, and 2 months in "cold and dry" weather), and (iii) a one-time 2-hour visit of Rong Cave by a tourist. The various seasonally-adjusted estimates for utility workers, tour guides, and one-time visitors entering 
Nguyen Thi Anh Nguyet, et al./Vietnam Journal of Earth Sciences 40 (2018)

Rong Cave, as well as estimated cumulative annual inhalation doses, which are listed in Table 2 , are based on average seasonal concentrations of both radon isotopes using the UNSCEAR (2000) algorithm. Exposure of utility workers, tour guides, and one-time visitors in
Rong Cave is less than 20.5, 0.9 and $0.06 \mathrm{mSv}$ $\mathrm{a}^{-1}$, respectively, in the longest "warm and wet" season. The maximum cumulative exposure affects utility workers during the warm and wet season reaching approximately $24.7 \mathrm{mSv} \mathrm{a}^{-1}$ (Table 2).

Table 2. Time spent in Rong Cave and estimated total annual inhalation dose from ${ }^{222} \mathrm{Rn}$ and ${ }^{220} \mathrm{Rn}$ in Rong Cave for utility workers, tour guides and visitors by using the UNSCEAR (2000) algorithm. The year is divided into 6 months of 'warm and wet' outside weather and 3 months each of two types of 'cold' weather

\begin{tabular}{|c|c|c|c|c|c|c|c|c|c|c|}
\hline \multicolumn{2}{|c|}{ Season } & \multirow[t]{2}{*}{$\begin{array}{l}\text { People enter- } \\
\text { ing Rong Cave }\end{array}$} & \multicolumn{2}{|c|}{$\begin{array}{l}\text { Average radon } \\
\text { concentration } \\
\left(\mathrm{Bq} \mathrm{m}^{-3}\right)^{*}\end{array}$} & \multicolumn{2}{|c|}{$\begin{array}{l}\text { Number of hours } \\
\text { spent in Rong Cave }\end{array}$} & \multicolumn{3}{|c|}{$\begin{array}{c}\text { Seasonal inhalation } \\
\text { dose }(\mathrm{mSv})\end{array}$} & \multirow{2}{*}{$\begin{array}{l}\text { Cumulative } \\
\text { annual inhala- } \\
\text { tion } \\
\text { dose }\left(\mathrm{mSv} \mathrm{a}^{-1}\right) \\
\mathrm{n}\end{array}$} \\
\hline Time & Weather & & ${ }^{222} \mathrm{Rn}$ & ${ }^{220} \mathrm{Rn}$ & per day & in season & ${ }^{222} \mathrm{Rn}$ & ${ }^{220} \mathrm{Rn}$ & ${ }^{222} \mathrm{Rn}+{ }^{220} \mathrm{Rn}$ & \\
\hline \multirow{3}{*}{$\begin{array}{l}\text { May to } \\
\text { October } \\
\text { (i.e. } 180 \\
\text { days) }\end{array}$} & \multirow[t]{3}{*}{$\begin{array}{l}\text { Warm } \\
\text { and wet }\end{array}$} & $\begin{array}{l}\text { Utility } \\
\text { workers }\end{array}$ & \multirow{3}{*}{5956} & \multirow{3}{*}{492} & 4 & 720 & 16.2 & 4.3 & 20.5 & \multirow{3}{*}{24.7} \\
\hline & & Tour guides & & & 2 & 30 & 0.7 & 0.2 & 0.9 & \\
\hline & & $\begin{array}{l}\text { One-time visi- } \\
\text { tors }\end{array}$ & & & 2 & 2 & 0.05 & 0.01 & 0.06 & \\
\hline \multirow{3}{*}{$\begin{array}{c}\text { November } \\
\text { to January } \\
\text { (i.e. } 90 \\
\text { days) }\end{array}$} & \multirow[t]{3}{*}{$\begin{array}{l}\text { Cold and } \\
\text { wet }\end{array}$} & $\begin{array}{l}\text { Utility } \\
\text { workers }\end{array}$ & \multirow{3}{*}{873} & \multirow{3}{*}{546} & 4 & 360 & 1.2 & 2.4 & 3.6 & \multirow{3}{*}{1.8} \\
\hline & & Tour guides & & & 2 & 90 & 0.3 & 0.6 & 0.9 & \\
\hline & & $\begin{array}{l}\text { One-time visi- } \\
\text { tors }\end{array}$ & & & 2 & 2 & 0.01 & 0.01 & 0.02 & \\
\hline \multirow{3}{*}{$\begin{array}{l}\text { February to } \\
\text { April (i.e. } \\
90 \text { days) }\end{array}$} & \multirow[t]{3}{*}{$\begin{array}{l}\text { Cold and } \\
\text { dry }\end{array}$} & $\begin{array}{l}\text { Utility work- } \\
\text { ers }\end{array}$ & \multirow{3}{*}{206} & \multirow{3}{*}{74} & 4 & 360 & 0.3 & 0.3 & 0.6 & \multirow{3}{*}{$\leq 0.06^{* *}$} \\
\hline & & Tour guides & & & 2 & 60 & 0.05 & 0.05 & 0.1 & \\
\hline & & $\begin{array}{l}\text { One-time visi- } \\
\text { tors }\end{array}$ & & & 2 & 2 & $<0.01$ & $<0.01$ & $<0.01$ & \\
\hline
\end{tabular}

*(Nguyen Thuy Duong et al., 2016);** A visitor's inhalation dose depends on the season of a single 2-hour cave visit once per year

\section{Discussion of human exposure to radon radiation in Rong Cave}

Radon concentrations in Rong Cave varied among measurement campaigns and were highest during 'warm and wet' outside weather conditions, when the air temperature in Rong Cave was lower than outside air and ventilation was reduced to $0.01 \mathrm{~m} \mathrm{~s}^{-1}$ near the entrance (Nguyen Thuy Duong et al., 2016), because the cave's elevated entrance acts like a sill preventing the density-driven outflow of colder air from the cave's passage. Similar seasonal fluctuations in ventilation rate and radon concentrations have been reported from other caves, for example Postojna Cave in Slovenia (Gregoric et al., 2013) and Luray Caverns in Virginia, USA (Cigna, 2015). Rong Cave's maximum ${ }^{222} \mathrm{Rn}$ concentration of almost $6 \mathrm{kBq} \mathrm{m}{ }^{-3}$ exceeded Vietnam's recommended safety threshold of $200 \mathrm{~Bq} \mathrm{~m}$ of $^{-3}$ natural radon activity in buildings (TCVN 7889: 2008) by a factor of 30 (TCVN, 2008). Even during 'cold and wet' and 'cold and dry' weather conditions, parts of Rong Cave occasionally exceeded the safety threshold severalfold $\left(873 \mathrm{~Bq} \mathrm{~m}^{-3}\right)$, although at other times the ${ }^{222} \mathrm{Rn}$ concentration essentially matched the TCVN recommendation at values of $206 \mathrm{~Bq}$ $\mathrm{m}^{-3}$ (Figure 2). Radon concentrations also often exceeded the UNSCEAR-recommended action safety threshold of $300 \mathrm{~Bq} \mathrm{~m}$ (UNSCEAR, 2008).

International organizations and authorities in Vietnam have not yet announced any official radiation safety standard for ${ }^{220} \mathrm{Rn}$. However, UNSCEAR (1993) mentions a safety 
level for ${ }^{220} \mathrm{Rn}$ in air of only $\sim 10 \mathrm{~Bq} \mathrm{~m}^{-3}$, which is far below Rong Cave's mean ${ }^{220} \mathrm{Rn}$ concentration of 70 to $550 \mathrm{~Bq} \mathrm{~m}^{-3}$ one meter above the clay-rich floor, close to where people breathe (Figure 2). ${ }^{220} \mathrm{Rn}$ concentrations in the air closer to clay surfaces are routinely far higher because the parental isotopes of ${ }^{220} \mathrm{Rn}$ reside in minerals and ${ }^{220} \mathrm{Rn}$ 's short half life of -55.6 seconds limits transport in nonturbulent air (Meisenberg et al., 2017). The ventilation rates of caves have limited influence on near-surface concentrations of ${ }^{220} \mathrm{Rn}$. Therefore, even during "cold and wet" weather conditions, when ${ }^{222} \mathrm{Rn}$ may be limited due to increased ventilation of cave air $\left(0.032 \mathrm{~m} \mathrm{~s}^{-}\right.$ 1 according to Nguyen Thuy Duong et al., 2016), the ${ }^{220} \mathrm{Rn}$ concentration in cave air will remain high near the ground and may significantly endanger utility workers not only via its own decay, but even more so by the decay of its metallic radioactive daughter nuclides.

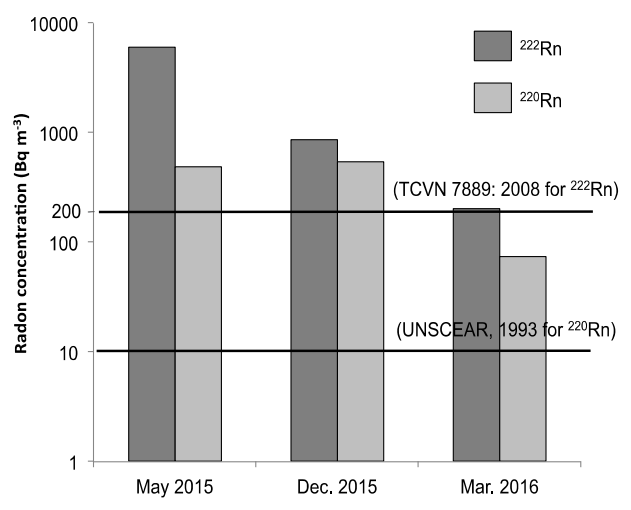

Figure 2. Average radon concentrations one meter above the ground in Rong Cave compared to TCVN 7889: 2008 for ${ }^{222} \mathrm{Rn}$ and compared to UNSCEAR (1993) for ${ }^{220} \mathrm{Rn}$ safety threshold recommendations

The IAEA (1996) recommends a maximum annual inhalation dose of $1 \mathrm{mSv} \mathrm{a}^{-1}$. While exceptional cases may call for an annual dose to reach $5 \mathrm{mSv} \mathrm{a}^{-1}$, the average dose over five years should not exceed $1 \mathrm{mSv} \mathrm{a}^{-1}$. Table 2 suggests that touristic short-term visits in Rong Cave, whose exposure is less than
$0.06 \mathrm{mSv} \mathrm{a}^{-1}$, do not significantly add to a person's annual inhalation dose. The situation for tour guides is less clear, because the radonrelated inhalation dose from a 2-hour cave visit is not equally distributed throughout the various weather conditions of a year. The cumulative exposure of a tour guide in seasons that reach approximately $1.8 \mathrm{mSv} \mathrm{a}^{-1}$ may exceed the IAEA-recommended annual inhalation dose if his activities are centered on months with high radon concentrations in cave air, for instance "warm and wet" and "cold and wet" seasons. The long time spent year-round by utility workers in Rong Cave clearly and unavoidably causes a high annual inhalation dose that stands in violation of IAEA safety guidelines by a factor of up to $\sim 25$ (Figure 3).

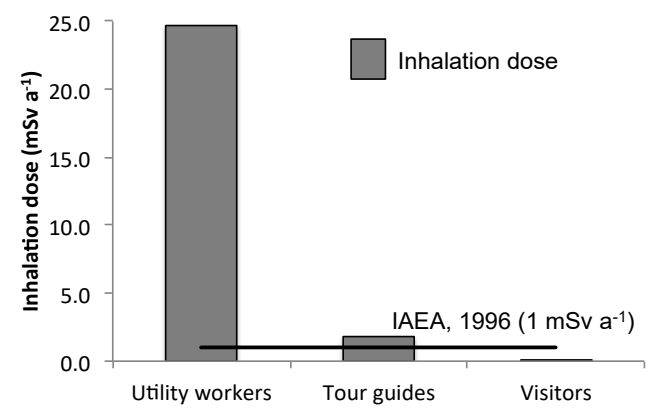

Figure 3. Estimated annual inhalation doses for utility workers, tour guides, and one-time visitors in Rong Cave. The horizontal line represents the recommended safety threshold (IAEA, 1996)

The exposure can be marginally reduced if major maintenance and construction activities in the cave can be avoided during times of high radon concentrations during 'warm and wet' weather conditions. Ideally most maintenance in the cave should be performed during 'cold and dry' weather. Moisture enhances the emanation efficiency of radon from sediment (e.g., Markkanen and Arvela, 1992; Morawska and Phillips, 1993). Proper timing of utility work would require feedback from a reliable radon monitoring device in the cave to 
Nguyen Thi Anh Nguyet, et al./Vietnam Journal of Earth Sciences 40 (2018)

workers about dangerous working conditions. Staff should be rotated frequently when work in the cave is unavoidable in the presence of high radon concentrations, or utility workers with known past elevated exposure to radon should work for some years only on infrastructure outside of the cave. Respiratory filters can be employed to reduce the inhaled amount of ${ }^{220} \mathrm{Rn}$ and metallic daughter nuclides suspended in cave air (Wang et al., 2011). We note that some of the utility workers live in mud-built houses that expose their inhabitants to additional significant concentrations of ${ }^{220} \mathrm{Rn}$ that is exhaled from dry interior mud walls and the mud floor (Nguyen Thuy, et al., 2017).

\section{Conclusions}

Radon concentrations in the air of Rong Cave exceeded WHO-recommended safety thresholds (UNSCEAR, 1993, 2008) except from February to April during 'cold and dry' weather conditions. Rong Cave's thoron $\left({ }^{220} \mathrm{Rn}\right)$ concentrations are far higher than the respective WHO-recommended safety level. ${ }^{222} \mathrm{Rn}$ concentrations in Rong Cave exceed the TCVN-7889: 2008 safety recommendation of $200 \mathrm{~Bq} \mathrm{~m}^{-3}$ (TCVN, 2008).

Radon concentrations were highest during 'warm and wet' outside weather conditions and lowest in 'cold and dry' weather. Depending on cumulative seasonal and annual exposure times in the cave, the inhalation doses for utility workers, tour guides, and touristic visitors vary greatly. Short-term visitors are insignificantly affected by radiation in Rong Cave $\left(\leq 0.6 \mathrm{mSv} \mathrm{a}^{-1}\right)$ according to IAEA recommendations (1996). However, radon isotopes and their radioactive decay products may pose a significant health risk to utility workers and tour guides. The estimated total inhalation dose for utility workers and tour guides exceeded IAEA-recommended values (1996), especially for utility workers. We propose time-management strategies and tech- nical solutions towards a reduction of radiation doses for utility workers and tour guides in Rong Cave.

\section{Acknowledgements}

This research is funded by Vietnam National Foundation for Science and Technology Development (NAFOSTED) under grant number 105.99-2016.16 to Nguyen Thuy Duong. This study was spawned during cave field work supported by the U.S. Department of Energy, Office of Science, Office of Basic Energy Sciences, Chemical Sciences, Geosciences, and Biosciences Division under Award Number DE-SC0006978 to Arndt Schimmelmann. We thank Dr. Thomas Streil from the $\mathrm{SARAD}^{\circledR} \mathrm{GmbH}$ for expert advice on radon measurement. The authors thank Ms. Schimmelmann Minh Ngọc for providing cultural liaison and helping with logistics.

\section{References}

Cigna A.A., 2005. Radon in caves. Interna-tional Journal of Speleology 34(1-2), 1-18.

Ha Giang Statistics Office (GSO), 2016. Statistical Yearbook of Ha Giang 2015, 404 pages, Ha Giang (in Vietnamese).

Dumitru O.A., Onac B.P., Fornós J.J., Cosma C., Ginés A., Ginés J., Merino A., 2015. Radon survey in caves from Mallorca Island, Spain. Science of The Total Environment, 526, 196-203.

Etiope G., Martinelli G., 2002. Migration of carrier and trace gases in the geosphere: An overview. Physics of the Earth and Planetary Interiors, 129(3-4), 185204.

Global Geoparks Network (GGN), 2010. Dong Van Karst Plateau Geopark. http://www.globalgeopark.org/aboutggn/list/vietnam /6509.htm

Gregorič A., Vaupotič J., Šebela S., 2013. The role of cave ventilation in governing cave air temperature and radon levels (Postojna Cave, Slovenia). International Journal of Climatology 34, 1488-1500.

Gunn J., 2003. Radon in caves. In Gunn J (Ed.): Encyclopedia of Caves and Karst Science. Fitzroy Dear- 
Vietnam Journal of Earth Sciences, 40(2), 117-125

born (Taylor \& Francis Books, Inc.), London, UK, 617-619.

International Atomic Energy Agency (IAEA), 1996. Quality assurance for safety in nuclear power plants and other nuclear installations. Safety standards and guides, In: Safety series Q1-Q14. A publication within the Nuss programme.

International Commission on Radiological Protection (ICRP), 2003. Database of Dose Coefficients: Workers and Members of the Public, Version 2.0.1 (CD- ROM), Elsevier Science, Amsterdam.

International Commission on Radiological Protection (ICRP), 2010. Lung cancer risk from radon and progeny and Statement of radon. ICPR Pub. 115. Ann. ICPR, 40(1).

Markkanen M., Arvela H., 1992. Radon emanation from soils. Radiation Protection Dosimetry, 45(1-4), 269-272.

Meisenberg O., Mishra R., Joshi M., Gierl S., Rout R., Guo L., Agaarwwal T., Kanse S., Irlinger J., Sapra B.K., Tschiersch J., 2017. Radon and thoron inhalation doses in dwellings with earthen architecture: Comparison of measurement methods. Science of The Total Environment, 579, 1855-1862.

Morawska L., Phillips C.R., 1993. Depend-ence of the radon emanation coefficient on radium distribution and internal structure of the material, Geochimica et Cosmochimica Acta, 57(8), 1783-1797.

Nguyen Thuy Duong, Nguyen Van Huong, Arndt Schimmelmann, Nguyen Thi Anh Nguyet, Dang Thi Phuong Thao, Ta Hoa Phuong, 2016. Radon concentrations in Karst caves in Dong Van Karst plat-eau. VNU Journal of Science - Earth and Environmental Sciences, 32(2S), 187-197 (in Vietnamese).

Nguyen Thuy Duong, Arndt Schimmelmann, Nguyen Van Huong, Agnieszka Drobniak, Jay T. Lennon, Ta Hoa Phuong, Nguyen Thi Anh Nguyet, 2017. Subterranean microbial oxidation of atmospheric methane in cavernous tropical karst. Chemical Geology, 466, 229-238.

Nguyen Van Huong, Nguyen Thuy Duong, Nguyen Thi Anh Nguyet, Pham Nu Quynh Nhi, Dang Thi Phuong Thao, Tran Van Phong, Nguyen Ngoc Anh, 2016. Cenozoic tectonics in Dong Van karst plateau recorded in karst cave system. VNU Journal of Science - Earth and Environmental Sciences, 32(2S), 45-58 (in Vietnamese).

Nguyen Anh Nguyet, Nguyen Thuy Dương, Arndt Schimmelmann, Nguyen Van Hu-ong, Ta Hoa Phuong, Dang Phuong Thao, Ma Ngoc Giang, 2016. Radon concentration in Rong cave in Dong Van Karst Plateau Geopark. Proceeding of International Symposium Hanoi Geoengineering 2016, 248-253.

The United Nations Scientific Committee on the Effects of Atomic Radiation (UNSCEAR), 1993. Report to the General Assembly, with scientific annexes. United Nations sales publication E.94.IX.2. United Nations, New York.

The United Nations Scientific Committee on the Effects of Atomic Radiation (UNSCEAR), 2000. UNSCEAR 2000 Report. In: Sources, vol. I. United Nations, New York.

The United Nations Scientific Committee on the Effects of Atomic Radiation (UNSCEAR), 2008. UNSCEAR 2000 Report. In: Sources, vol. I. United Nations, New York.

Vietnamese Standards (TCVN 7889:2008), 2008. Natural Radon activity in buildings-Levels and general requirements of measuring methods, Ministry of Science and Technology and Ministry of Construction (Viet Nam) (in Vietnamese).

Tong-Dzuy Thanh, Vu Khuc (Eds), 2011. Stratigraphic units of Vietnam. Vietnam National University Publisher, 553p.

Walia V., Lin S.J., Fu C.C., Yang T.F., Hong W.L., Wen K.L., Chen C.H., 2010. Soil-gas monitoring: A tool for fault delineation studies along Hsinhua Fault (Tainan), Southern Taiwan. Applied Geochemistry, 25(4), 602-607.

Wang J., Meisenberg O., Chen Y., Karg E., Tschiersch J., 2011. Mitigation of radon and thoron decay products by filtration. Science of the Total Environment, 409(19), 3613-3619.

World Health Organization (WHO), 2000. Air Quality Guidelines for Europe, (2nd edition). WHO Regional Publications, European Series, 91, Chapter 8.3 Radon. 

Vietnam Journal of Earth Sciences, 40(2), 117-126 